\title{
Effect of hydrogen cyanamide on bud emergence in wine grapes
}

Budburst occurred earlier in treated Cabernet Sauvignon vines (left) than in untreated vines (above). The same effect occurred in Chardonnay but not Zinfandel.

John H. Foott

$\mathrm{H}_{3}$ cynamide has been shown by other researchers to improve the amount and uniformity of budburst in grapevines in warm areas with inadequate chilling, such as California's Coachella Valley. A trial was conducted in 1985 to learn whether hydrogen cyanamide would also improve budburst in cooler areas, especially on cane-pruned vines of varieties that have budburst failure in the middle of the canes. The trial also included one Zinfandel vineyard to determine if the chemical would affect budburst on a spurpruned variety.

\section{Methods}

The three vineyards used in the trial were all in the Edna Valley of San Luis Obispo County. Planting density was 622 vines per acre. After pruning, 25 vines were sprayed with 2.5 percent hydrogen cyanamide ( 5 gallons per 100 of 50 percent solution) with a hand sprayer using about 50 gallons per acre; 25 vines were left untreated as a control (table 1). The trial design was a randomized complete block with 25 replications of single vines.

Budburst percentages were recorded on two dates for Chardonnay and Cabernet Sauvignon and once for Zinfandel. Shoots and flower clusters were counted.

Just before harvest, 100 berries were sampled from treated and untreated vines for a determination of maturity. Yields of individual vines were recorded on October 9 for Zinfandel (picked for White Zinfandel wine) and on October 15 for Chardonnay and Cabernet Sauvignon.

\section{Results}

In this trial, budburst occurred earlier in treated than in untreated Cabernet Sau- vignon vines, but there were no differences in final budburst. Budburst also occurred earlier in treated Chardonnay, and final budburst was higher than in untreated vines. No differences were seen in Zinfandel.

Berry maturity, as measured by soluble solids, titratable acidity, and $\mathrm{pH}$, was higher in treated than untreated Cabernet Sauvignon and Chardonnay (table 2). Yields in these test plots were significantly higher in vines treated with hydrogen cyanamide. In the Zinfandel plots, however, there were no differences in fruit characteristics.

Hydrogen cyanamide is not registered for use in California.

John H. Foott is Farm Advisor, Cooperative Exten sion, University of California, San Luis Obispo County.
TABLE 1. Budburst in three vineyards sprayed with hydrogen cyanamide, 1985

\begin{tabular}{lccccc}
\hline \multirow{2}{*}{ Grape variety } & Pruned & Sprayed & Evaluated & Treated & Nontreated \\
\cline { 5 - 6 } Chardonnay & \multirow{2}{*}{ Feb 4 } & Feb 5 & Mar 9 & 57.8 & 20.5 \\
& & & Mar 29 & 84.7 & 70.3 \\
Cabernet & Feb 8 & \multirow{2}{*}{ Feb 9 } & Mar 29 & 60.0 & 0.0 \\
Sauvignon & & & Apr 11 & 96.0 & 92.2 \\
Zinfandel & Feb 8 & Feb 9 & Mar 29 & 97.0 & 97.1 \\
\hline
\end{tabular}

TABLE 2. Effects of hydrogen cyanamide applied to three wine grape varieties

\begin{tabular}{lccccccc}
\hline $\begin{array}{l}\text { Variety and } \\
\text { treatment* }\end{array}$ & $\begin{array}{c}\text { Bud } \\
\text { burst }\end{array}$ & $\begin{array}{c}\text { Clusters } \\
\text { per } \\
\text { vine }\end{array}$ & $\begin{array}{c}\text { Shoots } \\
\text { per } \\
\text { vine }\end{array}$ & OBrix & $\begin{array}{c}\text { Titratable } \\
\text { acidity }\end{array}$ & $\begin{array}{c}\text { Yield per } \\
\text { vinet }\end{array}$ \\
\hline $\begin{array}{l}\text { Chardonnay } \\
\text { Untreated }\end{array}$ & 70 & 58 & 34 & 21.3 & 1.14 & 3.33 & $14.1 \mathrm{~b}$ \\
$\quad \begin{array}{l}\text { HCN } \\
\text { Cabernet }\end{array}$ & 85 & 70 & 29 & 22.7 & 1.03 & 3.35 & $19.1 \mathrm{a}$ \\
$\begin{array}{l}\text { Sauvignon } \\
\text { Untreated }\end{array}$ & 92 & 89 & 63 & 22.7 & 0.86 & 3.31 & $18.9 \mathrm{~b}$ \\
$\quad$ HCN & 96 & 100 & 68 & 23.7 & 0.81 & 3.38 & $21.0 \mathrm{a}$ \\
$\begin{array}{l}\text { Zinfandel } \\
\text { Untreated }\end{array}$ & 98 & $\ddagger$ & 44 & 20.4 & 1.17 & 3.06 & $27.8 \mathrm{a}$ \\
HCN & 97 & $\ddagger$ & 44 & 20.2 & 1.14 & 3.06 & $31.3 \mathrm{~b}$ \\
\hline
\end{tabular}

- $\mathrm{HCN}: 2 \%$ hydrogen cyanamide $\left(\mathrm{H}_{2} \mathrm{CN}_{2}\right)$

$\dagger$ Mean separation by Duncan's multiple range test. Numbers followed by different letters are significantly different at the $5 \%$ level. $\mp$ Not counted. 